\title{
Leukocyte adhesion deficiency type III
}

INSERM

\section{Source}

INSERM. (1999). Orphanet: an online rare disease and orphan drug data base. Leukocyte adhesion deficiency type III. ORPHA:99844

Leukocyte adhesion deficiency type III (LAD-III) is a form of LAD (see this term) characterized by both severe bacterial infections and a severe bleeding disorder. 